\title{
6
}

\section{Mana on the Move: Why Empirical Anchorage Trumps Philosophical Drift}

Thorgeir Kolshus

\section{The mixed blessings of broader attention}

At a time when the channels for academic publication seem to multiply at a staggering rate and the writer-to-readership ratio approaches 1 , our fellows' gaze becomes an ever scarcer commodity. Attentionseeking behaviour has hardly been decorous in academia, and this time-honoured detached intellectualism has limited the genres for underlining novelties. But new realities require new measures. And the hullabaloo surrounding the presentation of a manifesto for an 'anthropology of ontology' at the 2013 American Anthropological Association meetings had the makings of a successful public relations campaign, gobsmacking into silence those who had regarded the various theoretical takes that are subsumed under this label as mere analytical frameworks rather than The Next Big Thing.

But for some lucky few, staying put seems to be the better option. Those of us who engage the ethnographic specificities of mana have over the decades at irregular intervals had the rare privilege of finding the attention of the academic community seeking us. 
The contributions to this volume are written under a moon when mana yet again is in vogue. The introduction to the inaugural issue of the widely praised HAU: Journal of Ethnographic Theory (da Col and Graeber 2011), presents mana as a prime example of the theoretical promises of ethnography-derived concepts. And the influential and youthfully provocative volume Thinking Through Things (ed. Henare, Holbraad and Wastell 2007) gives mana a prominent place in its search for new anthropological ways of approaching the material (for a critique of the epistemological shortcomings of this volume, see Zeitlyn and Just 2014). In his chapter in Thinking Through Things, Martin Holbraad even seems willing to let mana decide the course for new theoretical innovations, 'by giving the transgressive potential of mana full rein so as to reach new analytical departures - thinking neither about it, nor just with it, but through it' (2007: 200). ${ }^{1}$ He follows up the call from the volume's introductory chapter, which argues against the engrained association between theory and generalisation with universal applicability as the ultimate limit-cum-goal, and suggests that the epistemological status of anthropology is better compared to that of philosophy than that of science (2007: 190).

At first reading, I appreciated both the attention and Holbraad's magisterial overview of the mana debate. He also argues well for why mana holds particular promise, as having the capacity to move us beyond the ontological distinction between concrete things and abstract concepts (2007: 193), thus adding a somewhat new dimension to the debate while displaying a motivation that goes further than a (highly understandable) desire to stand on the shoulders of giants. Nonetheless, his conviction of mana's 'generative potency' to anthropological theory seemed hyperbolic and, I readily admit, rather bewildering. This was, in other words, fertile ground for anthropological debate, which he, tongue-in-cheek only halfway, holds is 'supposed to be motivated by misunderstanding' (2007: 191). I also found that he too casually dismisses the case against the universal application of ethnographically derived concepts, a position that he attributes to anthropology's disciplinary commitment to give ethnography right of

1 Holbraad's choice of words in this quote fits almost too neatly with Anne Salmond's assessment of spatial metaphors that characterises the Anglo-American vocabulary addressing knowledge acquisition - which she convincingly shows is highly culture-specific (Salmond 1982). A feminist reading of Holbraad's association between intellectual clarity and penetrative imagery might also have pointed out an undercurrent of axiomatic androcentrism. 
way, 'so that anthropological theory has tended to disappear down the hatch of ethnographic particularism' (2007: 189). It seems that Miles's law, 'where you stand depends on where you sit', holds true also for the anthropological community, since I fail to recognise Holbraad's depiction of the current valuation between ethnography and theory. From my corner of the anthropological world, theoretical innovation (frequently in the form of rehashing old insights with new terms) consistently outranks ethnographic persistence (see Kolshus 2014 for a historic parallel to William H. Rivers' work).

In order to overcome anthropology's enduring impasse after two decades of progressively incapacitating hyper-reflexivity, attempts at theoretically rebooting the discipline are more than welcome. Even so, Holbraad's remoulding of mana, for all its virtuous intentions, appeared at first glance somewhat colonising. And with every rereading, I have found his approach increasingly nebulous. This is partly due to his philosophical agenda, which, judged from my critical realist social science standpoint, elicits a detached theological exegesis rather than an experience-near ethnography of the notion of aché in Afro-Cuban Ifá (cf. Keesing 1987). But even when tentatively assessed with reference to his own agenda, I find it hard to see how Holbraad's endeavour escapes rendering mana with virtually the same general applicability that is the hallmark of the science-inspired epistemological tradition he purports to challenge. And since the various theoretical and analytical stances subsumed under the 'anthropology of ontology' heading have introduced a plethora of conceptual neologisms, some of which he also engages in his analysis (2007: 209-16), I anticipate that the multiple revisits of the century-old animism/animatism debate (recent additions to the ones Holbraad mentions are, for instance, Pedersen 2011; Willerslev 2011, 2013) will bring about the conceptual tools that invite both theoretical friction and cross-cultural comparison, without the burden of culture-specific associations that expose them to the nuisance of ethnographic vetoes.

Holbraad is of course not accountable for my intellectual shortcomings. However, I cheekily suggest that my bewilderment also is due to a portion of scholarly fastidiousness that is required in order to identify not only the potential for generalisations but also its limits. Standing on the shoulders of giants like Claude Lévi-Strauss, Marcel Mauss and Émile Durkheim, to mention but a few, provides a marvellous view of the summits. But it is easy to lose touch with the continuous 
landscape underneath, and, possibly pushing the analogy a bit too far, this renders the giants with feet of clay. It is hard to understand how Holbraad's ambitions for mana as an analytic term can avoid leaving it empirically disembodied and consequently render the thinking that is done 'through' it no more ethnographically driven than any other form - while simultaneously providing the user with the false impression that this is less 'as if' than more intangible analytical concepts. In short, it gains legitimacy from the virtue of an ethnographic accuracy that is little but imagined, and it loses that twin purpose of analytical concepts, that is the ability to put things together and tell things apart. ${ }^{2}$ Providing parochial correctives to these unacknowledged shortcomings is the obligation of mana scholars, however vexing they might appear.

\section{Mota mana writ large}

My approach to Holbraad's arguments is without doubt informed by academic turf-watching. Mana is very much my business. When in search of a fieldwork site in $1996,{ }^{3}$ I had the highly serendipitous fortune of choosing the island of Mota, from which the first ethnographic descriptions of Melanesian mana originate. Robert Henry Codrington wrote the famous passages that triggered the ongoing debate (1891: 116-21). ${ }^{4} \mathrm{He}$ was uniquely positioned to do so after 25 years of close association with recruits from Mota to the Anglican Melanesian Mission's central school on Norfolk Island and more than

2 In the 1960s, Isaac Schapera was invited to give a lecture series at the University of Oslo. Students who had read his works from southern Africa were unexcited by the news, since they found his writings tedious, focusing on ethnographic details and with few wider-reaching analyses. Much to their surprise, his lectures were remarkably innovative and theoretically sophisticated. When someone mustered the courage to ask why he rarely included theoretical discussions in his works, Schapera replied, 'I write for eternity' (Odd Are Berkaak, personal communication, 20 August 2014).

3 I have had two long-term fieldwork trips on Mota, 1996-97 and 2002-03, in addition to a five-week fieldtrip in 2012. These are coupled with research in the extensive archives related to the Melanesian Mission. Since the language of Mota for various reasons was used as a lingua franca throughout Anglican Melanesia from the 1860s to 1920, a remarkable collection of previously unaccessed material has become available to me - including the first private letters written by Melanesians, in which also is found the first mention of mana in the nominalised form by a local teacher on Nggela in the Solomon Islands (Ralph Kinogi, letter to R.H. Codrington, 2 January 1884, Rhodes House Library, Oxford, MSS Pac s5).

4 The bulk of Codrington's analysis was presented in the Journal of the Anthropological Institute of Great Britain and Ireland (1881), 10 years before he published The Melanesians. 
10 stays of up to three months' duration on the island proper. This gifted scholar coupled unsurpassed language proficiency with a remarkably reflexive methodological approach, arguably turning him into the most prominent missionary ethnographer in the history of anthropology, on top of his being a pioneer linguist (Stocking 1995). ${ }^{5}$ The fierceness in Roger Keesing's repeated charges on Codrington 100 years later (see for instance Keesing 1984, 1985, 1987, 1992) is a mark of the distinction of Codrington's work. Keesing's revisit is not paying heed to a methodologically and intellectually flawed ancestor; he assesses Codrington's work almost in a manner worthy of a contemporary contribution. Keesing's stinginess with compliments is a compliment in itself. In an article that should be read as paired with the current chapter (Kolshus 2013), I partly exonerate Codrington of Keesing's criticism by showing how the Mota version of the mana concept, which Codrington used as his point of departure for his generalisations, was influenced by a more nominalised Polynesian form of mana - through extensive pre-European relations with Tikopia, exacerbated by the first missionaries' knowledge of Maōri and their consequent search for Polynesian cognates in the Mota language. ${ }^{6}$ Keesing's insistence that Melanesian mana never was nominalised before Codrington's misconceptions derailed the academic community's elaborations of the term, which again influenced how Melanesians conceived it, is consequently not only a colonising approach, it is also most probably historically incorrect (cf. François 2013) and is based on a seemingly wilful misrepresentation of Codrington's complex depiction of the nature of Mota mana. The Codrington/Keesing confusion is a case for caution to anyone who harbours ambitions of saying something both specific and unifying regarding the many different cloaks in which Pacific mana appears (see Firth's insightful 'methodology' for mana research in 1967: 174, 178). Keesing's search after the original

5 Many will argue that Maurice Leenhardt outranks Codrington, since he inspired the influential literature on Melanesian personhood. However, juxtaposing his Do Kamo (1979) with Codrington's The Melanesians shows a remarkable difference in ethnographic accuracy and methodological sophistication. I suspect that Leenhardt's high standing is a consequence of secondary enthusiasm rather than first-hand reading, exacerbated by the theoretical agenda of a generous biographer (Clifford 1992). For an assessment of Codrington's methodology and ability as an ethnographer, see Kolshus (2011, 2013).

6 Linguist Alexandre François, who has done research on most of the languages in the Banks and Torres groups and in the Temotu Province in the southern Solomon Islands, has recently shown that *mana is nominalised throughout the Banks and Torres (François 2013). In the Mota language, mana does operate as a noun, meaning 'a power', with a corresponding verbal form, manag, that denotes the act of imparting something with mana. 
and 'untainted' Melanesian mana (1984) appears as a quixotic and rather unusual project for a social scientist to engage in. There is, of course, nothing wrong with engaging questions of origins. But in the process, Keesing loses touch with a crucial aspect of mana, namely how its conceptualisation changes with time and across space. His version of mana therefore seems atemporal and mono-spatial; it is the traditionalist Kwaio understanding writ large.

Part of Keesing's case against Codrington is facilitated by The Melanesians' shortage of empirical anchoring of mana. Raymond Firth, who was very appreciative of Codrington's depiction of mana, regretted that this first-class ethnographer failed to provide examples of mana in action. One reading of Codrington's take on mana suggests that his ethnographic base was so solid that he did not even consider the possibility of there being other mana notions out there. He simply read the island Melanesian world through a Mota prism, as Keesing would do for the Kwaio 100 years later.

In this chapter, I intend to rectify Codrington's omission and address the ways mana has been conceptualised and perceived on Mota during my 18 years of research engagement with Mota. I will first show the (limited) use of mana in the non-churchly domain, before moving on to its omnipresence in Mota Anglican theology and liturgy and how it renders ordained clergy with powers that are used far beyond a restricted ministerial domain. The Anglican majority's views on mana are finally contrasted with those held by the members of the Pentecostal Assemblies of God (AOG), which was established on Mota around the year 2000 and which has gradually become 'localised'which has had consequences for their conceptualisation of mana and the work of the Holy Spirit, again showing the agility of an age-old notion. Mana is indeed on the move, spatially and conceptually.

At the outset, I would like to emphasise one aspect of particular comparative interest, namely the relation between mana and the moral. In Codrington's depiction of Melanesian mana, he insists that it is an amoral force, in the respect that there is no expectation that this extra-human capacity should be applied to the benefit of others. As we will see, this is echoed in contemporary perceptions of mana, not only on Mota but more or less throughout the Anglican area of northern Vanuatu and south and central Solomon Islands. As a consequence, within this area there is no notion that mana can be 
abused or misused. In short, with the capacity follows entitlement. The outcome can be cause for moral judgment, but mana in itself is not part of the assessment. This is in contrast to what Mary Kawena Pukui, E.K. Haertig and Catherine A. Lee report from Hawaii (1972) and is a twin reminder of the requirement for caution in generalising from specific instances and of the requirement for soberness in regard to the uses of experience-near notions and ethnographic concepts as analytical tools.?

\section{Mana on Mota today}

So then, when and in which contexts is mana made manifest on Mota 150 years after Codrington first visited the island? The short answers are 'rarely' and 'few', which to the critical eye account for Codrington's ethnographic omissions. Mana in action might simply not have been observed nor broadly addressed (however, see Codrington 1891: 57), but could easily have remained a reference for ritual specialists, for people of a philosophical disposition, and for those who had reached the top ranks of the Suqe-graded male society, to whom Codrington in his private journal referred as 'the old gentlemen' and with whom he reported enjoying sitting and talking - even expressing admiration for their polite but determined rejection of the Christian faith. But the historians' adage that absence of evidence is not evidence of absence has some salience here, and current praxis should not be projected retrospectively upon the past. Too, even though mana is rarely heard in everyday parlance, this could be a consequence of the term

7 In our approach to Pacific, or even Austronesian, mana, Rodney Needham's concept of 'polythetic classification' (1975) might be useful, since it refers to how a wide range of phenomena may be cognitively united without requiring any one shared trait. Apart from their sharing the four-letter structure, $\mathrm{ABCD}$ does not seem directly associable with EFGH. However, the two digitally disparate phenomena are analogically connected through the existence of for instance CDEF. For instance, the Mota understanding of mana as an amoral capacity is mirrored in popular Christianity on Austronesian Madagascar: "The power of [the mana-cognate] hasina thought to permeate all living and inanimate things in the universe is fundamentally amoral and can cause good and harm, according to whether it is handled right or not' (Skeie 2011: 168; see also Bloch 1989: 64-67). This suggests that we might be dealing with a polythetic continuum, with the Mota version sharing some traits with the Malagasy form while sharing others with the Hawaiian manamanifestation and providing a link between the two. The discussion over where the cutting point for mana-notions should be is of course highly relevant here. Should for instance the concept of evur from Fang of Cameroon be included, as Boyer (1986) suggests? And if so, is it sound to exclude the aché in the Cuban Ifá cosmology, which also has its origins in West Africa? And what about the various mana-cognates found in Native American cosmologies, etc.? 
having been appropriated by the Anglican Church, and subsequently having become part of a specialised vocabulary restricted to domains where the outcome exceeds what could reasonably be expected and consequently must be of an extra-human origin. This would also be consistent with my hypothesis regarding the Polynesian influence on Mota mana, both through extensive contact with Tikopia over the centuries and through the Māori bias of the first missionaries and Bible translators (Kolshus 2013).

The first time I met mana in a non-liturgical setting was right after I had become sufficiently skilled in the Mota language to no longer have to rely on Bislama. It should be noted that this was before I had read The Melanesians, which even to Keesing's exacting taste should leave me untainted by what he somewhat disparagingly calls 'Codringtonian orthodoxies' (1992: 233). Judah, ${ }^{8}$ one of the practitioners of traditional medicine, had come to examine Veronica, a 13-year-old girl who for several weeks had been suffering from fatigue and stomach pains. ${ }^{9}$ She had already seen a diviner, but her condition had worsened after a temporary recovery, and her parents summoned Judah. He had learnt the method from his adoptive father and had decided that he eventually would pass it on to one of his sons again as part of his inheritance. ${ }^{10}$ He charged 500 vatu, approximately \$US5, for every successful treatment, which by Mota standards is a substantial extra income. Judah's procedure was widely regarded as being among the most effective on the island. Rumours even had it that he had saved patients whose hearts had stopped beating. After having administered his treatment, Judah explained to me how it worked. Before daybreak he would pick a red coconut and sing 17 different songs in archaic versions of northern Vanuatu languages. This would manag the coconut (bestow it with mana). In order to make sure that I got the message, he repeated the sentence in Bislama, 'givim kokonas ia fulap paoa' ('make this coconut full of power').

8 Most of the names in this chapter are pseudonyms.

9 Her parents had sent her to an Anglican secondary boarding school on neighbouring Vanua Lava, but she had returned to Mota because of her symptoms. Parents of my disposition would interpret these as signs of homesickness mixed with school anxiety.

10 On Mota, land is transferred matrilineally while rights to trees a man plants during his lifetime go to his children. Moveable property and knowledge of traditional medicine and other zealously guarded secrets may be passed on as the holder sees fit. 
Judah's initial instruction, coupled with increased language proficiency, made me more attentive to mana. But the term rarely appeared, even to a keenly listening ear. Whenever it occurred, it would be in sentences such as 'ó mana tapena apena' ('there is mana to it'), or even 'ó mana tapena we pōa' ('its mana is great'). Within the medical domain, mana separates remedies and treatments that have an effect from those that do not, regardless of whether these were traditional or introduced. Consequently, penicillin had mana when it first arrived along with the Mota dispensary sometime around 1970, because it so effectively combatted yaws that had been endemic on the island. But now, people say that it has lost its mana, since it has little effect on the condition due to the prevalence of penicillin-resistant strains of bacteria and other germs. And since there are no other varieties of antibiotics available, the majority seek traditional treatments or ask the clergy or the members of the Melanesian Brotherhood, an indigenous Anglican order, to pray for them (Kolshus forthcoming; see also Oroi, this volume). Panadol (paracetamol) is still widely regarded as having mana, however. According to most Motese it does not only have a palliative but also a curative effect, a conviction they continue to hold in spite of my imprudent suggestions to the contrary. When the pain from a chronic condition returns, this has a different cause and must be treated accordingly.

Every now and then I would ask different people, 'What is mana?', without further specification or contextualisation, in order to confirm the futility of questions only an anthropologist might ask (Gow 2006). Invariably they would inquire whether it was the mana associated with the Church I had in mind. Painfully aware of how unsophisticated my questioning was, on top of its being virtually unanswerable, I would proceed by asking them what their first association would be. Charitably indulging my quirks, virtually everybody pointed to the Bible. Some would not distinguish mana from the manna that the Lord showered upon the people of Israel during their exodus from Egypt (Exodus 16:4; for further discussion see Tomlinson 2006), while many brought up the Gifts of the Spirit and proceeded from these to talk about special capacities in general. Good fortune in fishing, for instance, was a sign that somebody had mana. Judging by the initial inquiries, I got the impression that there was no exegetic tradition surrounding mana outside the churchly realm. Mana seemed to be a label put on any phenomenon, capacity or talent that had an effect that exceeded 
the expected, consistent both with Codrington's description of mana being the cause of any 'conspicuous success' (1891: 120), Keesing's characterisation of mana as 'retrospective pragmatism' (1984: 149), and Bradd Shore's concept of 'generative potency' (1989). Likewise, to my initial disappointment, my adoptive father Paul appeared to hardly have heard the term when I first asked him about it during a communal evening meal, even though he is an expert on the Tamate secret male associations and the laws and procedures of the Salagōō, the dwellings of these associations. Only after much deliberation was he able to relate it to 'miracles'. But his ignorance turned out to be a remarkably well-played act of deception, in order to hide one of the most zealously guarded secrets of the Tamate from me, as at that point I had not yet been initiated. One of the men playing a key role in the workings of the Tamate is indeed said to 'have mana'. This, however, is o gene vatnñoreag, we vatnñoreag (a thing so very secret), that it would only be revealed to members on a need-to-know basis.

Resembling Codrington's mention of 'conspicuous success', 'luck' was an association shared by a number of Motese in relation to mana (da Col 2012; Feinberg 1996: 63). There is a range of stories on Mota and the other Banks Islands involving people who seem to have an everlasting supply of money - a trait that is highlighted by the chronically penniless state of most Mota households. Jacob, whose grandfather Clement had arrived from Tikopia, told me that he had been one of these lucky few. No matter how much he spent, he would always have 200 vatu (approximately \$US2) in his pocket. His wife suspected foul play and accused him of having an affair. He adamantly denied this, but she insisted that he told her the truth - which he eventually did, grudgingly, knowing that this would put an end to his luck, since fortunes like his usually relied on the origins of the wealth being kept a secret. He rounded off his confession with shouting at his wife, 'Now look what you've done, you've ruined us!' Jacob's case was uncommon, as he was unaware of either the source of the money or how he first came to realise his blessing. Others who had been on the receiving end of enduring endowments or one-off windfalls mentioned receiving messages from deceased relatives in dreams or reported seeing an elusive figure pointing towards a particular spot where money would be found. 
The Church had an ambivalent attitude towards cases like Jacob's. There was of course nothing wrong with being fortunate, particularly when this encouraged generosity rather than parsimony in the recipient. But practices that required individuals to keep secrets and withhold information from their spouses and relatives were necessarily of an antisocial nature and consequently not reconcilable with being a good Christian. Even worse, from a Church point of view, were the rare cases that involved magical procedures that paralleled those of the Church. Mark, an old man in my village, passed away a few months into my first fieldwork. People held that the cause of death was his use of a particular kind of garden magic that required stealth in order to have the desired effect. If anyone knew what he was up to before he had reached his garden to carry out the procedure, or if a particular species of bird started to sing, the magic would harm him. On this particular occasion, the priest did speak out, since Mark had shown a lack of confidence in the blessings of our Lord, the source of all life. He had also shown disregard or mistrust in the power of the 50-yearold covenant, o vatavata, between the Mota people and the Lord, by which the people had sworn on the priest's consecration cross never again to use harmful magic. In return, the island gained the Lord's protection (Kolshus forthcoming). This caused any attempt to inflict injury by magical means, ò gagapalag we tatas (literally bad objectives), to rebound on the perpetrator while leaving the intended victim safe from harm. And even though garden magic did not necessarily qualify as harmful in itself, the requirement for silence and secrecy made it suspect nonetheless. The man should therefore have realised that someday he would pay for his hubris, which consisted in relying on the ability of unknown forces to secure a rich harvest rather than putting his fate in the hands of the Lord.

\section{Mana and Anglo-Catholic theology}

Every Mota man and woman insisted that the covenant against sorcery had saved their people from extinction. Consequently, cases like Mark's have a reassuring effect on the Motese, since they prove that the covenant is still effective and that God's mana administered by the Church is more effective than the mana that can be invoked through old practices. This realisation also brought about the conversion of the island in the first place: the Church's rituals and other procedures were 
found to have a greater transformative potential than those associated with the old beliefs (see Firth 1967, 1970: 342-43; Scott 2007: xxx; Tomlinson 2006: 174-75; White 1991: 166-67). It is the ordination of the Bishop, who in his turn ordains the priests and the deacons, that assures the correct transmission of ministerial powers and authority. ${ }^{11}$ Historically, the Anglican Church's theological emphasis on the apostolic origins of the episcopacy, that is the uninterrupted chain of episcopal investiture starting with the first apostles, has wavered. And it was not until the Oxford Movement's increasing influence from the 1830s onwards that apostolic succession became more widely acknowledged as part of the dogmatic foundations of the Anglican Church. Later, it was its even more ritualistically oriented Anglo-Catholic vein that came to dominate the Melanesian Mission. ${ }^{12}$ This theological orientation, which still dictates the liturgical practices and teachings of the Anglican Church of Melanesia, stresses the dogma of apostolic succession even more. I do not find it very far-fetched to suggest a parallel between pre-Christian notions of transfer of mana and the doctrine of apostolic succession. And the virtues of a Church established by Christ's choice of Peter as the rock on which to build it (Matthew 16:18), carrying forth the notion of successive transfers of this original endowment of powers, is a potent reminder of the powers of the clergy (see Hilliard 1978: 234). When it resonates so well with how other extraordinary abilities are believed to be transmitted, the mana of the Church is integrated into Mota cosmology, both being encompassed by and expanding Mota understandings of efficacy and agency.

11 During Firth's 1966 fieldwork, a Tikopia teacher explained the internal ranking of the clerical offices: 'Bishop, priest, deacon, teacher, brother [tasiu, member of the Melanesian Brotherhood] — in that order; then he added significantly: "Now, their mana is great, that of the Brothers and of the Bishop"' (Firth 1970: 342-43).

12 The Anglo-Catholic leanings were a matter of deliberate choice, for the exact same reasons that Anglican congregations in working-class parishes applied incense more liberally and otherwise appealed to other senses than mere intellect (Hilliard 1978: 233). In the periodical of the Melanesian Mission (MM), influential missionary and highly competent ethnographer Walter Durrad revealed the purpose behind the MM's gradual turn towards Anglo-Catholicism:

The staid and sober services of half a century ago ... seem to make no appeal to these emotional people, who are like Southern Europeans in love of colour and dramatic element. We need to get rid of the drab from the picture and give some appeal to the imagination and the eye. These people are children. With them laughter and tears are close together, and they are as easily moved to the one as to the other. The cold, solemn, calculating, serious, reasoning, Anglo-Saxon is surprised at such emotionalism and apparent inconsistency, but it is certain that we must strive to take account of the native viewpoint if we are ever to influence the people as a whole. (1912: 343) 
It is in the Mota liturgy that mana most clearly manifests itself. The doxology of the Lord's prayer, 'For thine is the kingdom, the power, and the glory', is translated as 'Namoma ō marana, wa o mana, wa o leñas'. 'God turmana' (lit. God essence of mana) equals 'Almighty God'; and the power of God and the Holy Spirit is consistently referred to as mana. Mana also brings about the transubstantiation of the bread and wine during the Eucharist. In the eyes of the public, the celebration of the Eucharist, which takes place every Sunday in addition to the more than 100 holidays listed in the calendar of the Church of Melanesia, is a persuasive display of the priest's access to God's mana and, consequently, their full dependence on their clergy. His summoning forth the revitalising gifts of Holy Communion by uttering the right words and assuming the time-honoured bodily stances is a persuasive exhibition of mana, confirming his indispensability, while the Lord, through the successful transubstantiation, affirms the legitimacy of the priest's office and of the qualities that set him apart from ordinary men and women (see Firth 1967: 364). In the Book of Common Prayer, the procedures of baptism, the other major Anglican sacrament, supports the communicative aesthetics of clerical generative powers. It also clearly shows how attuned Anglican dogmatics and ritual are to Motese notions of mana. The liturgical section Thanksgiving over the water, during which regular water becomes Holy Water, involves the celebrant touching the baptismal font. To more evangelically minded Anglicans this act might be seen as a symbol of the transformation, but to the Motese it is done in order to effect this transformation. Holy Water becomes infused with, well, generative potency. It does not only have the ability to turn small children into children of God and render them with a second soul (ō atai tape vasōgōrōño) which carries a Christian name,$^{13}$ in addition to the soul of the world (o atai ta lo marama) which is called by a Mota name (see Kolshus forthcoming). It also serves as an all-purpose medicine, and it is a means to temporarily fend off threats from malevolent beings while seeking the more permanent protection of the clergy. Consequently, every family will keep a small bottle of

13 In this context, 'Christian' refers to names associated with the world beyond Vanuatu. Historically, these have usually been missionary heroes and former Anglican bishops of Melanesia, but in recent decades, names of world leaders and soccer stars have become popular. Nixon, Clinton and Saddam Hussein all have their Mota namesakes. 
Holy Water in its house. During my last fieldwork, Mama Japhet, ${ }^{14}$ the newly appointed district priest from Ureparapa some 50 kilometres away, carefully displayed the dramaturgical consequences of this particular theology. After having read the words of the Thanksgiving prayer in a decelerating manner, he conspicuously made his finger enter the water and kept it there in silence for some very long seconds before slowly retracting it.

Also on the level of liturgical grammar, the differences between the priest and his parish are made manifest. As is the case with many Oceanic languages, Mota operates with a distinction between plural personal pronouns that include or exclude the addressee. ${ }^{15}$ When speaking to the congregation, laypeople, catechists and (usually) deacons use the first-person plural inclusive nina, while the priest will use the second-person plural kamiu. When addressing God on behalf of the congregation, the priest refers to them as neira, third-person plural, while the others use the first-person plural exclusive kamam. This is both indicative of and informs laypeople's understanding of the clergy's capacities. Priests are people of a different kind because of their inauguration, with the ability to bring about outcomes that exceed the expected - which sums up Codrington's descriptions of the Motese understandings of mana that he encountered 150 years ago and is how mana still is conceived.

\section{Clerical mana and moral misgivings}

The folk model of clerical power holds that the clergy can distribute God's blessings and punishments at their own discretion. This perception is shared by the majority of Anglican priests with whom I discussed the matter on Mota and elsewhere. A few did

14 This equivalent of 'Father' is an abbreviation of the Mota term for 'father's elder brother', and is still used by most Anglican Melanesians when addressing a priest (see Oroi, this volume). Mama Japhet had recently come to Mota as a chaplain for the Melanesian Brotherhood household there, but since the one remaining Mota priest had been defrocked and no other replacement could be found, he was ordered by the bishop to oversee the whole island. The fact that Mota, the cradle of Anglicanism in Melanesia and source of missionaries and clergy for well over a century, was no longer self-supplied with clergy, caused much embarrassment and collective ministerial soul-searching.

15 In Mota, the renderings of 'we' (inclusive), 'we' (exclusive) and 'you' also depend on whether two, three or more-than-three people are included, which leaves Mota with 15 personal pronouns. 
acknowledge the theological and ministerial awkwardness of this view, which bestows them with powers that they held rested with the Lord and for which they merely served as mediators. But they nonetheless chose not to confront these beliefs, with pragmatic reference to a greater political good. With a barely functioning local leadership structure and negligible state presence, the Church is for all practical purposes the only generally recognised authority and consequently the only institution that holds some authority over people's lives also beyond the churchly domain. Undermining public reliance on the clergy's abilities to act with efficacy upon the world might lead to a polity crisis that would aggravate the living conditions of their flock. Faced with these prospects, pastoral concerns weighed against theological exactness.

Furthermore, the minor and more substantial miracles that are attributed to the clergy and the Tasiu, members of the indigenous monastic order The Melanesian Brotherhood, maintain people's faith in an almighty God and His worldly representatives. Importantly, so do the occasional malicious acts committed by the same men of the cloth. ${ }^{16}$ My initial encounter with this phenomenon took place a few weeks into my first fieldwork. It involved Cleyton, who ran a little business importing powdered kava, which was in high demand since the local kava crops had been wiped out in a drought the year before. Cleyton sold kava cheaper than anyone else, but made up for the difference by never granting credit. One of the priests, Mama Selwyn, equally known for his desire for kava as for his insolvency, wanted to buy some bags on tick. Neither flattery nor sweet promises could circumvent Cleyton's sensible business policy. When the mama realised that he was getting nowhere, he declared in the presence of several others that something bad would happen to Cleyton's body. One week later, during a football game attended by most Motese including Selwyn, Cleyton severed his big toe, with blood gushing and the digit dangling from a piece of skin. The injury left him indisposed for well over a month. Immediately after the incident, we witnessed Mama Selwyn's friends openly congratulating him on his achievement. People were indeed upset by the affair. But counter to my expectations, their grievances against the priest did not involve

16 See John P. Taylor (2008: 59-60) for an old case from north Pentecost, and Sabine Hess (2009) for a new example from Vanua Lava. Both these islands belong to the traditional Anglican area of northern Vanuatu. 
any notion of abuse of power, merely regular charges of inflicting injury on a fellow citizen. It became clear that the mama's power to influence God's will was seen to be on a par with the operation of a machete or another weapon. The fact that he had made God punish a man who had done nothing wrong did not elicit resentment against either him or the Church.

I was too apprehensive to discuss this case with Mama Selwyn himself. However, during a visit to Port Vila some months later, I spent an evening with Mama Harry, who for several years had served on Mota. I knew him by reputation, since my adoptive mother's mother Hansen, who is the most renowned traditional medical expert on Mota, insisted that he had instructed God to strike her with a serious illness that almost had killed her two years earlier. A number of other families had also been adversely affected by his powers, and he was widely regarded as being responsible for the death of at least one member of his flock, in addition to allegedly withholding prayers that would have saved several others. Eventually, the parishioners' contribution to his salary trickled to virtually nothing - which is the common way to air discontent and press for a priest's resignationand he was reassigned by the bishop. Mama Harry turned out to be a very talkative and sociable man, who soon would instruct me on his control over the weather conditions. Because of his consecration as a priest, he said, he was able to coerce the sun and the rain to follow his commands - before suddenly correcting himself and emphasising that it of course was the work of God, through him. Likewise, the ability to cure diseases, and even raise the dead, was granted him through the Bishop's inauguration, the evidence of which was manifest in the cross he wore hanging from a silver necklace. Harry did not mention the flip side of his influence over life and death, and I was reluctant to ask. I still regret this omission, and I am quite certain that he would have answered my questions. Because even though our exchange of anecdotes showed that I had close relations with some of those who held him responsible for their tribulations, he showed no signs of embarrassment. Quite the opposite, he almost seemed to invite questions regarding his role in their hardships. I was only prevented by my entrenched understanding that a priest's mana could only be used for good, which would make suggestions to the contrary highly inappropriate. In other words, my initial reaction to what I regarded as blatant abuse of mana by Harry and other members 
of the clergy made me read such acts as being of an antisocial nature. In hindsight, I realise how flawed this deduction is. The allotment of blessings and misfortunes is a priest's pastoral right. Sickness and even death brought about by the clergy are a consequential part of the introduction of the more potent mana of the Church, enhanced by the monopoly on generative potential that followed from the covenant. And even though people respond with distress when men of the Church use their mana to harm others, the situation is after all much more predictable when the ability to impart injury by non-corporeal means lies exclusively with a handful of people who are known to all. More importantly, this 'darker' side of the clergy's abilities assures the congregation that they have rightful access to God's mana-which means that the required blessings will also flow through the clergy whenever need be.

\section{Pentecostalism and the mana of the Holy Spirit}

The distribution of mana through the Anglican clerical hierarchy puts laypeople in a position of dependency and consequently exposes them to the idiosyncrasies and whims of individual members of the clergy. Frustration over this privileged access to generative potency was a prime mover behind the single greatest change on Mota since the covenant that eradicated sorcery, namely the conversion of Garamal village to the Assemblies of God, an American Pentecostal Church with a global outreach. This was the first non-Anglican Church to have a presence on the island that is widely regarded as the cradle of Anglicanism in Melanesia. During my second long-term fieldwork in 2002-2003, I spent much time discussing the background for the schism two years before, as well as how the AOG members experienced their new life. As far as theological deliberations were concerned, the leading characters behind the split were remarkably candid, stating matter-of-factly that the choice of AOG had been purely accidental. Andrew, the elected Garamal village headman, had gone to the provincial capital on Vanua Lava in anger, following the sudden climax of a longstanding land conflict involving an Anglican deacon, in search of a new Church. The only requirement was that it had to be non-Anglican. The clerk of the provincial court happened to be the leader of the local AOG congregation, and she gave him an outline of their history and practices. Andrew readily admitted that he had not paid much attention to dogmatic specificities. The main attraction had 
been the fact that the Church was American. After he returned, with promises of a new church building to go with the new faith, along with a few bags of second-hand clothes, the approximately 40 Garamal villagers converted en masse. Soon, other disgruntled Anglicans had joined them and the village almost tripled in size, going from being the smallest to the second largest in little over a year. ${ }^{17}$

During the many conversations I had with people in Garamal about their relationship with the Anglican majority, they emphasised repeatedly that their only desire was to be on friendly terms. The most important thing was that they all believed in the same one God, they said, even though some Anglicans acted as if this was not the case. I knew that the actions of some Anglican clergy had affected several of the converts particularly harshly, with Mama Harry allegedly being responsible for the death of at least one of their relatives. But I never heard them openly criticise Anglican clergy. However, much of the praise for their own spiritual leader, Pastor Walter from neighbouring Mota Lava, seemed to be founded on a negation of the qualities of Walter's Anglican counterparts, emphasising his good nature (matevui), as a generous man who was in control of his temper. When I asked what the main differences were between their current denominational association and their lives as Anglicans, many mentioned the feeling of proximity to the acts of worship. The service was more of a companionship where people got together to praise the Lord rather than a gathering where they depended on middle-men to take responsibility for the proceedings. Sarah, an elderly woman whom I knew well from my first fieldwork, said that even though she had been an Anglican her entire life, she never had understood much of what was going on during Mass. She sang the hymns but did not know the meaning of many of the liturgical procedures. Worse, she said, was that the clergy did not seem to mind people's ignorance. The AOG, on the other hand, depended on her taking part. She concluded, coyly but proud, 'Wa lōkenake ō lölömaran me kalō galean' ('So now I feel a bit brighter').

17 A clear majority of these were associated with one particular political party, the Union of Moderate Parties (UMP), which historically is closely connected to the Francophone parts of Vanuatu. This party also claimed stewardship of Mota's 'community boat', a 16-foot aluminum dinghy, since it was donated by the French on the eve of independence. Consequently, the dinghy was relocated from the only natural landing place on the island to a site that is much more exposed to wind and weather, making landings a hazardous business for boat and people alike. 
I asked them rather bluntly whether they felt somewhat closer to God now that they no longer depended upon the clergy as officiators. Again, they politely dodged the question. Joel, Sarah's husband, started talking about a subterranean water source they recently had discovered, which along with the rain they had been receiving provided them with more than enough water-in stark contrast to the rest of Mota, which in 2003 suffered yet another serious drought. Given the context and his choice of wording, he seemed to attribute their abundant supply to blessings brought them by their more direct relation with the Lord. Others seconded Joel and mentioned that during the past couple of years, they had on a number of occasions witnessed how rain had fallen exclusively on the western part of Mota, where Garamal was the only village to benefit from it. They stressed that they did not keep this blessing (sōgove) to themselves, but did their best to share with those who were in need of or requested their help. As part of their diaconal service, the AOG regularly sent water to the school and the teachers, most of whom came from islands with ample water supply and therefore threatened to leave whenever their water tanks at irregular intervals would run dry.

An important part of the office of the Anglican clergy is to use his rapport with the Lord to manipulate the weather (Kolshus forthcoming). Droughts were frequent and nobody would blame these on the Church. But a mama is expected to bring about sufficient rain when water shortage jeopardises a major feast or when the nonMotese teachers threaten to leave the school and the island. He should also do his best to divert the course of devastating cyclones. During Christmas 2002, when Category 5 cyclone 'Zoe' was moving towards us after wreaking havoc on Tikopia, the resident priest Mama Malakai led a late-night service asking the Lord that this cup should pass us by. Anglicans felt reassured that Mota would not be harmed-until news reached us that immediately after the service, Malakai had left for a cave on his wife's matrilineal land that served as a cyclone shelter. People were in disbelief. Open criticism of a mama is rarely heard and particularly not in a time of crisis when faith in the measures at hand, which includes a mama's mana, is of the essence. But several men made subdued remarks disputing whether Malakai trusted his powers to sway the Lord's will. And if he did not have faith in their privileged relationship, then how could we? 
It was precisely this being at the mercy of clerical caprice that the AOG members had escaped through their conversion. And they obviously felt empowered by their move. They also pointed to their services as testimonies of the presence of the Holy Spirit, again by implication indicating that this was not the case with the modes of worship of their old Church. While the Anglican liturgical order ensured the repeated display of the transformative powers of the clergy, the spontaneity (albeit already ritualised) of the AOG services was proof of a living Church, with people falling over with convulsions, entering trance-like states, and speaking in tongues. In addition, the preferred posture of the Anglican parishioners, heads bowed in a subordinate manner, was inverted by the AOG members, standing upright, heads high, raising their hands towards Heaven. I tried to pursue the nature of the gifts of grace and whether these in any way could be related to mana, but my questioning was much too contrived even for these very forthcoming respondents. They were also reluctant to use the word mana in any sense. And since they also preferred to say 'Holy Spirit' instead of the time-honoured ' $\bar{O}$ vui we rōño', I saw this as expressing a desire to theologically detach themselves from their Anglican backgrounds by applying a new vocabulary befitting their new creed.

\section{Mana anew, again}

When I returned in 2012, I met a Pentecostal Church that seemed to have come of age. Some 80 members remained, and they professed to have almost worn themselves out carrying sand and material for an impressive 200 square metre concrete building that served the dual purpose of church and school. My first impression confirmed the view of many Anglicans I had talked to prior to my visit; namely that the days of vibrant spiritualism were long gone. A pastor had recently arrived from Mota Lava to look after the congregation, assisted by his wife from Epi, an island much further south, who also was responsible for the kindergarten. But the vigorous passion with which the two led the Sunday service I attended was far from being mirrored by the assembly. People in Garamal had also become lax on punctuality, a marked difference from what had been the case nine years before, when their strict timekeeping and ability to synchronise their efforts and movements had been key points of AOG pride. The worship also had an unmistakable air of following a script, albeit unwritten. 
And there was no speaking in tongues or possessions by the Spirit, which once was commonplace. Numerous appeals from the pastor and his guitar-playing and lead-singing wife that 'whoever feels like it' should worship with their hands in the air was only answered by one elderly woman, indulging them by raising her right arm half-way. I could not help feeling sorry for the couple, who responded to the seeming lack of resonance with even more frenzied attempts to ignite the assembly, thus highlighting the difference between their fiery selves and the apparent tepidity of the congregation.

However, after having spent the day in the village after the service, my initial understanding that AOG had moved from stirring revolution to stale convention had to be adjusted. During conversations with AOG members of both sexes and of various ages, I was impressed both by their theological savvy as well as their ability to convert dogmatic principles into practical ethics. But even more striking was their reflective attitude towards my nebulous question on the nature of their relationship with the Holy Spirit - whom they now, significantly, referred to as 'ō vui we rōño' rather than 'Holy Spirit'. Tonna, a man in his 30s, explained that whenever the Spirit made its presence and its will known, it felt like a whisper in one's ear. When many others confirmed his version with enthusiastic nodding, Tonna was quick to emphasise that apart from these whispers, he himself had not had any major experience of ō mana tape ō vui we rōño (the power of the Holy Spirit). This far in our conversation, I had deliberately avoided any mention of mana, in part because they had been so reluctant to use the term during my last visit. So I was quite surprised when Tonna referred to it so casually, thinking it to be either an idiosyncrasy or an attempt to accommodate my interests in traditions and purist Mota language. But the others followed suit, and 'mana' was used whenever our talk touched upon the work of the Holy Spirit. Their sense of being empowered was also more articulated than during my last visit. People talked about making direct appeals to the Spirit, and unlike nine years earlier they explicitly contrasted this with their Anglican kin's dependence on their clergy. In their community, women and men, young and old, might channel mana. After all, the effects of mana should reflect the will and wisdom of the Lord rather than the moods of a mama. 


\section{Mota mana on the move}

I left Garamal village with questions that I still struggle to come to terms with. In order to understand this increasing 'localisation' of the AOG theology, I find it helpful to return to the first Mota conversion, which took place between 1860 and 1880. The Christianisation of Mota did not substitute the existing mana beliefs. Quite to the contrary, Anglican dogmatics entail motifs that are highly adaptable to these very beliefs. What the new teaching brought was simply access to an even more powerful source of mana. And since the Melanesian Mission during the latter half of the nineteenth century subscribed wholeheartedly to Henry Venn's influential missiology (see Williams 2000), which insisted that God was not an Englishman and consequently that His words and wills could be revealed in all tongues and in many different cultural cloaks, this was realised also by the missionaries themselves - and capitalised upon by Codrington in his translations of the liturgy and the Bible into Mota. With reference to a principle of 'appropriation', by which only polygamy and infanticide were directly confronted by the European missionaries, they sought the practical realisation of Venn's aim for a 'euthanasia of the mission' (Darch 2009: 8-10). Appropriation meant that mana retained its basically amoral qualities. If you have it, you can use it. Undesired consequences attributed to the application of mana are definitely seen as ill-willed and 'bad', so it is not free from moral evaluation. But there is no expectation that acts should be benign simply because they involve mana. Mana is simply that, an ability to bring about outcomes that exceed what could be expected. ${ }^{18}$

With the AOG's emphasis on the individual relationship with God, the Mota version of mana has in a certain sense come full circle. Codrington's descriptions of how mana was distributed show that knowledge of how to bring about mana effects was a carefully guarded secret, usually passed on towards the end of a person's life. With the introduction of the mana of the Church, access to the most coveted transformative potential was through the Anglican hierarchy-

18 Since Mota was used as a lingua franca throughout Anglican Melanesia, these interpretations of the mana of the Church were introduced to areas with slightly different understandings of the nature of mana (Kolshus 2013) and have consequently become widely shared throughout Anglican Melanesia. This cosmological theme provides a comparative axis through an otherwise culturally and linguistically diverse area (Scott 2007; White 1991). 
which, incidentally, is not very different from the classic Polynesian understanding of mana as an attribute of, and constituting, social rank (see for instance Howard and Borofsky 1989b; Shore 1989). The most recent understanding of mana among the AOG members seems to include aspects of both the old and the new and renders it much more accessible to everyone: it is independent of the Church hierarchy sphere and is no longer a carefully guarded secret. As such, it brings to mind the emphasis on individualism that frequently is referred to as characterising charismatic and Pentecostal churches. The AOG understanding of mana implies full empowerment of the individual member, by which fortune and blessing become a property of the state of a person's faith. In other words, Mota mana remains on the move.

\section{Epilogue: The boundaries of mana motion}

The salient feature of mana as an analytic concept is its ethnographic groundedness. And since a general ethnography is an oxymoron, we inevitably must return to the question of where to draw the line of inclusion and exclusion, with reference to the age-old academic balancing act between simplicity and simplicisticism. At what point does 'thinking through mana' produce the 'world in general' that Clifford Geertz's apposite truism reminds us no one lives in? (1996: 262). This 'world in general' would turn mana into a concept 'at the servitude of all thought' (MacClancy 1986: 148), and consequently deprive it of exactly the experience-near qualities that made people look to mana in the first place. The promise of ethnographic theory lies not in its general applicability but in the ways it helps us pose different sets of questions. In other words, it is closely affiliated with the comparative method, with which it also shares challenges and shortcomings. Obstacles to generalisation have always kept anthropological theory on its toes. And I hold that the necessary nuisance of the ethnographic veto is as important as ever before in our disciplinary history. Steamrolling mana into ethnographic pulp in the manner of Holbraad does little to set anthropology on a more productive course. Quite the contrary, it dilutes the gains from an ethnographically informed discussion and threatens to bring us back to square one by arguing for a mana concept that might include all and everything and consequently becomes nothing in particular. 
So, flattering though the wider anthropological community's attention may be, it should not make us scale down our fastidiousness in order to accommodate overstretched claims. We should reclaim mana for the benefit of the social sciences rather than compartmentalising it by putting it in the service of 'turns' of mainly philosophical value. The service of mana researchers is to provide informed bumps in the intellectual road by our staying put and carrying on with our parochial business - so that whenever mana yet again comes into vogue and we again enjoy a wider readership, we can show how it has moved since mana's last call and remain uniquely positioned to identify the limits of its analytic potential.

\section{References}

\section{Archival repository}

Kinogi, Ralph, letter to R.H. Codrington, 2 January 1884. MSS Pac s5, Rhodes House Library, Oxford.

\section{Books, journal articles and chapters}

Bloch, Maurice. 1989. Ritual, History and Power. London: Athlone Press.

Boyer, Pascal. 1986. The 'empty' concepts of traditional thinking: A semantic and pragmatic description. Man (n.s.) 21: 50-64.

Cannell, Fenella (ed.). 2006. The Anthropology of Christianity. Durham, NC: Duke University Press.

Clifford, James. 1992. Person and Myth: Maurice Leenhardt in the Melanesian World. Durham, NC: Duke University Press.

Codrington, R.H. 1881. Religious beliefs and practices in Melanesia. Journal of the Anthropological Institute of Great Britain and Ireland 10: 261-316.

- 1891. The Melanesians: Studies in their Anthropology and Folklore. Oxford: Clarendon Press.

da Col, Giovanni. 2012. Natural philosophies of fortune-luck, vitality, and uncontrolled relatedness. Social Analysis 56: 1-23. 
da Col, Giovanni and David Graeber. 2011. Foreword: The return of ethnographic theory. $H A U$ l: vi-xxxv.

Darch, John H. 2009. Missionary Imperialists? Missionaries, Government and the Growth of the British Empire in the Tropics, 1860-1885. Eugene, OR: Wipf \& Stock.

Durrad, Walter J. 1912. Banks Islands report. Southern Cross Log (Australia/New Zealand version) 17: 337-43.

Feinberg, Richard. 1996. Sanctity and power on Anuta: Polynesian chieftainship revisited. In Leadership and Change in the Western Pacific. Essays Presented to Sir Raymond Firth on the Occasion of His 90th Birthday, ed. Karen Ann Watson-Gegeo and Richard Feinberg, pp. 56-92. London: Athlone Press.

Firth, Raymond. 1967. Tikopia Ritual and Belief. Boston: Beacon Press.

-1970. Rank and Religion in Tikopia. Boston: Beacon Press.

François, Alexandre. 2013. Shadows of bygone lives: The Histories of Spiritual Worlds in Northern Vanuatu. In Lexical and Structural Etymology, ed. Robert Mailhammer, pp. 185-245. Boston: De Gruyter.

Geertz, Clifford. 1996. Afterword. In Senses of Place, ed. Steven Feld and Keith H. Basso, pp. 259-62. Santa Fe, NM: School of America Research Press.

Gow, Peter. 2006. Forgetting conversion: The Summer Institute of Linguistics in the Piro lived world. In The Anthropology of Christianity, ed. Fenella Cannell, pp. 211-39. Durham, NC: Duke University Press.

Henare, Amiria, Martin Holbraad and Sari Wastell (eds). 2007. Thinking Through Things. Oxon: Routledge.

Hess, Sabine. 2009. Person and Place. New York: Berghahn.

Hilliard, David. 1978. God's Gentlemen. St Lucia: University of Queensland Press.

Höem, Ingjerd and Reidar Solsvik (eds). 2011 Identity Matters: Movement and Place. Oslo: The Kon-Tiki Museum Occasional Papers, vol. 12. 
Holbraad, Martin. 2007. The power of powder: Multiplicity and motion in the Divinatory Cosmology of Cuban Ifá (Or Mana, Again). In Thinking Through Things, ed. Amiria Henare, Martin Holbraad and Sari Wastell, pp. 189-225. Oxon: Routledge.

Howard, Alan, and Robert Borofsky. 1989a. Social organization. In Developments in Polynesian Ethnology, ed. Alan Howard and Robert Borofsky, pp. 47-94. Honolulu: University of Hawaii Press.

Howard, Alan, and Robert Borofsky (eds). 1989b. Developments in Polynesian Ethnology. Honolulu: University of Hawaii Press.

Hviding, Edvard and Cato Berg (eds). 2014. The Ethnographic Experiment: Rivers and Hocart in Melanesia, 1908. New York: Berghahn.

Keesing, Roger M. 1984. Rethinking 'mana'. Journal of Anthropological Research 40: 137-56.

- 1985. Conventional metaphors and anthropological metaphysics: The problematics of cultural translations. Journal of Anthropological Research 41: 201-17.

- 1987. Anthropology as interpretive quest. Current Anthropology 28: 161-76.

- 1992. Some problems in the study of oceanic religion. Anthropologica 34: 231-46.

Kolshus, Thorgeir. Forthcoming. Faith and demography: Sorcery, migration and Anglican mana. Journal of Pacific History.

_ 2011. Letters from Homes: Maintaining Global Relationships in the Victorian Age. In Identity Matters: Movement and Place, ed. Ingjerd Höem and Reidar Solsvik, pp. 51-62. Oslo: The Kon-Tiki Museum Occasional Papers, vol. 12.

_ 2013. Codrington, Keesing and Central Melanesian Mana: Two historic trajectories of Polynesian cultural dissemination. Oceania 83: 316-27.

—. 2014. A house upon Pacific sand: W.H.R. Rivers and his 1908 ethnographic 'survey work'. In The Ethnographic Experiment: Rivers and Hocart in Melanesia, 1908, ed. Edvard Hviding and Cato Berg, pp. 155-76. New York: Berghahn. 
Leenhardt, Maurice. 1979. Do Kamo: Person and Myth in the Melanesian World. Chicago: University of Chicago Press.

MacClancy, Jeremy. 1986. Mana: An anthropological metaphor for Island Melanesia. Oceania 57(2): 142-53.

Needham, Rodney. 1975. Polythetic classification: Convergence and consequences. Man (n.s.) 10: 349-69.

Nielssen, Hilde, Inger Marie Okkenhaug and Karina Hestad Skeie Skeie (eds). 2011. Protestant Missions and Local Encounters in the Nineteenth and Twentieth Centuries. Leiden: Brill.

Pedersen, Morten A. 2011. Not Quite Shamans: Spirit Worlds and Political Lives in Northern Mongolia. Ithaca, NY: Cornell University Press.

Pukui, Mary Kawena, E.K. Haertig and Catherine A. Lee. 1972. Nānā $i$ ke Kumu (Look to the Source). Honolulu: Hui Hānai.

Salmond, Anne. 1982. Theoretical landscapes: On a cross-cultural conception of knowledge. In Semantic Anthropology, ed. D. Parkin, pp. 65-87. London: Academic Press.

Schneider, David M. 1980 (2nd ed.). American Kinship. Chicago: University of Chicago Press.

Scott, Michael W. 2007. The Severed Snake: Matrilineages, Making Place, and a Melanesian Christianity in Southeast Solomon Islands. Durham, NC: Carolina Academic Press.

Shore, Bradd. 1989. Mana and tapu. Developments in Polynesian Ethnology, ed. Alan Howard and Robert Borofsky, pp. 137-73. Honolulu: University of Hawaii Press.

Skeie, Karina Hestad. 2011. Mission appropriation or appropriating the mission? Negotiating local and global Christianity in nineteenth and twentieth century Madagascar. In Protestant Missions and Local Encounters in the Nineteenth and Twentieth Centuries, ed. Hilde Nielssen, Inger Marie Okkenhaug and Karina Hestad Skeie, pp. 157-86. Leiden: Brill.

Stocking, Jr., George W. 1995. After Tylor. British Social Anthropology 1888-1951. Madison: University of Wisconsin Press. 
Taylor, John P. 2008. The Other Side. Honolulu: University of Hawai'i Press.

Tomlinson, Matt. 2006. Retheorizing mana: Bible translation and discourse of loss in Fiji. Oceania 76(2): 173-85.

Ward, Kevin and Brian Stanley (eds). 2000. The Church Mission Society and World Christianity, 1799-1999. Grand Rapids, MI and Cambridge: William B. Eerdmans Publishing Company/Richmond, Surrey: Curzon Press.

Watson-Gegeo, Karen Ann and Richard Feinberg (eds). 1996. Leadership and Change in the Western Pacific. Essays Presented to Sir Raymond Firth on the Occasion of His 90th Birthday. London: Athlone Press.

White, Geoffrey. 1991. Identity through History: Living Stories in a Solomon Islands Society. Honolulu: University of Hawai'i Press.

Willerslev, Rane. 2011. Frazer strikes back from the armchair: A new search for the animist soul. Journal of the Royal Anthropological Institute 17: 504-26.

- 2013. Taking Animism seriously, but perhaps not too seriously? Religion and Society 4: 41-57.

Williams, Peter. 2000. 'Not transplanting': Henry Venn's strategic vision. In The Church Mission Society and World Christianity, 1799 1999, ed. Kevin Ward and Brian Stanley, pp. 147-72. Grand Rapids, MI and Cambridge: William B. Eerdmans Publishing Company/ Richmond, Surrey: Curzon Press.

Zeitlyn, David and Roger Just. 2014. Excursions in Realist Anthropology. A Merological Approach. Newcastle: Cambridge Scholars Publishing. 
This text is taken from New Mana: Transformations of a Classic Concept in Pacific Languages and Cultures, edited by Matt Tomlinson and Ty P. Kāwika Tengan, published 2016 by ANU Press, The Australian National University, Canberra, Australia. 